\title{
Abundance estimation of Ixodes ticks (Acari: Ixodidae) on roe deer (Capreolus capreolus)
}

\author{
Christian Kiffner $\cdot$ Christina Lödige $\cdot$ Matthias Alings • \\ Torsten Vor • Ferdinand Rühe
}

Received: 23 November 2009/ Accepted: 30 January 2010/Published online: 4 March 2010

(C) The Author(s) 2010. This article is published with open access at Springerlink.com

\begin{abstract}
Despite the importance of roe deer as a host for Ixodes ticks in central Europe, estimates of total tick burden on roe deer are not available to date. We aimed at providing (1) estimates of life stage and sex specific (larvae, nymphs, males and females, hereafter referred to as tick life stages) total Ixodes burden and (2) equations which can be used to predict the total life stage burden by counting the life stage on a selected body area. Within a period of $1 \frac{1}{2}$ years, we conducted whole body counts of ticks from 80 hunter-killed roe deer originating from a beech dominated forest area in central Germany. Averaged over the entire study period (winter 2007-summer 2009), the mean tick burden per roe deer was 64.5 $(\mathrm{SE} \pm 10.6)$. Nymphs were the most numerous tick life stage per roe deer $(23.9 \pm 3.2)$, followed by females $(21.4 \pm 3.5)$, larvae $(10.8 \pm 4.2)$ and males $(8.4 \pm 1.5)$. The individual tick burden was highly aggregated $(k=0.46)$; levels of aggregation were highest in larvae $(k=0.08)$, followed by males $(k=0.40)$, females $(k=0.49)$ and nymphs $(k=0.71)$. To predict total life stage specific burdens based on counts on selected body parts, we provide linear equations. For estimating larvae abundance on the entire roe deer, counts can be restricted to the front legs. Tick counts restricted to the head are sufficient to estimate total nymph burden and counts on the neck are appropriate for estimating adult ticks (females and males). In order to estimate the combined tick burden, tick counts on the head can be used for extrapolation. The presented linear models are highly significant and explain 84.1, 77.3, 90.5, 91.3, and $65.3 \%$ (adjusted $R^{2}$ ) of the observed variance,
\end{abstract}

C. Kiffner $(\bowtie) \cdot$ C. Lödige $\cdot$ M. Alings $\cdot$ T. Vor $\cdot$ F. Rühe

Department of Forest Zoology and Forest Conservation incl. Wildlife Biology and Game Management, Büsgen-Institute, Georg-August-University Göttingen, Büsgenweg 3, 37077 Göttingen, Germany e-mail: ckiffne@gwdg.de

C. Lödige

e-mail: christinaloedige@ hotmail.com

M. Alings

e-mail: efrafa@web.de

T. Vor

e-mail: tvor@gwdg.de

F. Rühe

e-mail: fruehe@gwdg.de 
respectively. Thus, these models offer a robust basis for rapid tick abundance assessment. This can be useful for studies aiming at estimating effects of abiotic and biotic factors on tick abundance, modelling tick population dynamics, modelling tick-borne pathogen transmission dynamics or assessing the efficacy of acaricides.

Keywords Ectoparasite $\cdot$ Negative binomial distribution

\section{Introduction}

Ticks of the Ixodes ricinus (L.) complex (hereafter Ixodes ticks) are vectors of numerous arthropod-borne pathogens of medical and veterinary importance. These include Anaplasma phagocytophilum (causative agent of granulocytic anaplasmosis in humans, tick-borne fever in sheep and canine ehrlichiosis in dogs), Babesia divergens (causative agent of babesiosis in humans and redwater fever in cattle), Babesia venatorum (causative agent of babesiosis in humans), Rickettsia helvetica (causative agent for diffuse symptoms in humans), Borrelia burgdorferi (causative agent of Lyme disease) and tick-borne encephalitis virus (causative virus of tick-borne encephalitis) (for a review see Jongejan and Uilenberg 2004).

Roe deer (Capreolus capreolus) are important host species for Ixodes ticks in central Europe and might be important for the population dynamics of ticks. However, the role of roe deer for pathogen dynamics is largely unknown (e.g. Anaplasma phagocytophilum). For most of the tick-borne pathogens roe deer are believed to be dead-end or dilution hosts (e.g. Borrelia burgdorferi, tick-borne encephalitis virus), but deer potentially provide a platform for non-systemic pathogen transmission among co-feeding ticks (Jaenson and Tälleklint 1992; Matuschka et al. 1993; Kimura et al. 1995; Randolph et al. 1996; Bruno et al. 2000; Schmid and Ostfeld 2001).

Despite the importance of roe deer as host for Ixodes ticks and hence for associated tickborne pathogens in central Europe, few studies have investigated patterns of tick infestation on roe deer (Matuschka et al. 1993; Carpi et al. 2008). However, none of these studies aimed at estimating the total tick burden per roe deer individual, one of the most essential parameters for describing this host-parasite system. Studies on tick burdens on deer could be used for estimating effects of abiotic and/or biotic factors on tick densities (Carpi et al. 2008), or for assessing the efficacy of acaricide applications (Rand et al. 2000; Fish and Childs 2009; Pound et al. 2009). Furthermore, estimates of tick abundance on deer are useful for realistically parameterising models describing tick population dynamics and possibly tick-borne pathogen transmission dynamics (Randolph et al. 1996; Ogden et al. 1997; Randolph 2004; Hartemink et al. 2008).

Previous studies aiming at estimating tick burdens of domestic and/or wild mammals (Barnard and Morrison 1985; Bloemer et al. 1988; Barnard et al. 1989; Fourie and van Zyl 1991; Fourie et al. 1991; L'Hostis et al. 1994; Fourie and Kok 1995; Mathee et al. 1997; Ogden et al. 1998; Schmidtmann et al. 1998) used whole body counts on dead or live animals. Some of these studies provided simple linear models which can be used to predict total tick burdens based on tick counts on one or a few distinct host body parts (Barnard and Morrison 1985; Bloemer et al. 1988; Barnard et al. 1989; Fourie and van Zyl 1991; L'Hostis et al. 1994; Mathee et al. 1997). The term "density" of ticks which had been used by previous authors (Barnard and Morrison 1985; Bloemer et al. 1988; Barnard et al. 1989; Fourie and van Zyl 1991; L'Hostis et al. 1994; Mathee et al. 1997) described their estimates of tick abundance as density estimates. Here we use the terms tick "abundance" or 
"burden" as density is clearly defined as individuals/unit area, i.e. ticks $/ \mathrm{cm}^{2}$ (Sutherland 1996; Borchers et al. 2002). Neither previous authors nor we can provide this measure without estimating the surface area of parts or the entire host species.

Here, we conducted total tick counts on hunter killed roe deer in order to provide (1) estimates of stage/sex specific total Ixodes burden, and (2) equations which can be used to predict the total life stage burden by counting the number of ticks per life stage/sex on a selected body area.

\section{Materials and methods}

We opportunistically sampled 91 hunter-killed roe deer in the forested region east and northeast of Göttingen (centred at, $51^{\circ} 32^{\prime} 2^{\prime \prime} \mathrm{N}, 9^{\circ} 56^{\prime} 8^{\prime \prime}$ ), central Germany during regular hunting activities over a period lasting from winter 2007 to summer 2009 (NovemberDecember $2007 n=20$ roe deer; May-June $2008 n=20$; July-August 2008, $n=18$; November-December $2008 n=14$; May-June $2009 n=13$; July-August $n=6$ ).

The study area is dominated by mixed deciduous forests. The predominant tree species are European beech (Fagus sylvatica), Norway maple (Acer pseudoplatanus), European ash (Fraxinus excelsior) and sessile oak (Quercus petraea). The sites are often characterized by shallow limestone plateaus with rendzina soils and haplic luvisols, rich in nutrient supply, but rather poor in water supply during dry periods in summer. Some forest stands however are located on sandstone with sandy and loamy cambisols and these soils are characterized by lower nutrient contents but higher water availability, and are often covered by pure Norway spruce (Picea abies) stands. Depending on nutrient, water and light availability the ground cover with tree seedlings and herbaceous species is heterogeneous. Tree diameter or age classes vary on a small scale, providing enough shelter and nutrition for roe deer throughout the whole study area. The altitude above sea level ranges from 151 to $400 \mathrm{~m}$, the mean annual rainfall is $780 \mathrm{~mm}$ (370 $\mathrm{mm}$ in the growing season), and the average annual temperature is $7.8^{\circ} \mathrm{C}$ (Petritian et al. 2007).

Roe deer carcasses were disembowelled by the hunters and stored in cooling chambers at $2-8^{\circ} \mathrm{C}$ until examination. Within $16 \mathrm{~h}$ on average $(\mathrm{SE}: \pm 2.5 \mathrm{~h})$ after roe deer individuals had been shot, each carcass was examined by two observers wearing latex gloves. The carcass was divided into 6 distinct parts (head, neck, front legs, hind legs, sternum \& abdomen and rest of the body, Fig. 1). The roe deer skin was systematically inspected and palpated to detect all ticks. Sites heavily infested were consecutively searched and palpated by both persons. All ticks were removed from each body part with forceps. These ticks were immediately counted and recorded according to life stage and sex (larvae, nymphs, males and females, hereafter referred to as tick life stages). Finally, they were transferred to sampling tubes and stored at $-20^{\circ} \mathrm{C}$. All removed ticks belong to the Ixodes ricinus complex; no Dermacentor spp. (Koch 1844) were identified during this study.

\section{Statistical analysis}

For each tick life stage and roe deer body part we calculated mean $(\mu)$ tick numbers in absolute and relative terms (Table 1$)$ and the corresponding standard errors $( \pm \mathrm{SE})$. Since patterns of macroparasite burdens on wildlife hosts usually follow the negative binomial distribution which is described by $\mu$ and the inverse measure of aggregation $(k)$, we also calculated $k$ for the absolute tick burdens (Shaw et al. 1998): 
Fig. 1 Sketch outline of the tick collection sites on a roe deer (Capreolus capreolus) buck. Drawing: W. Tambour/J. Seelig

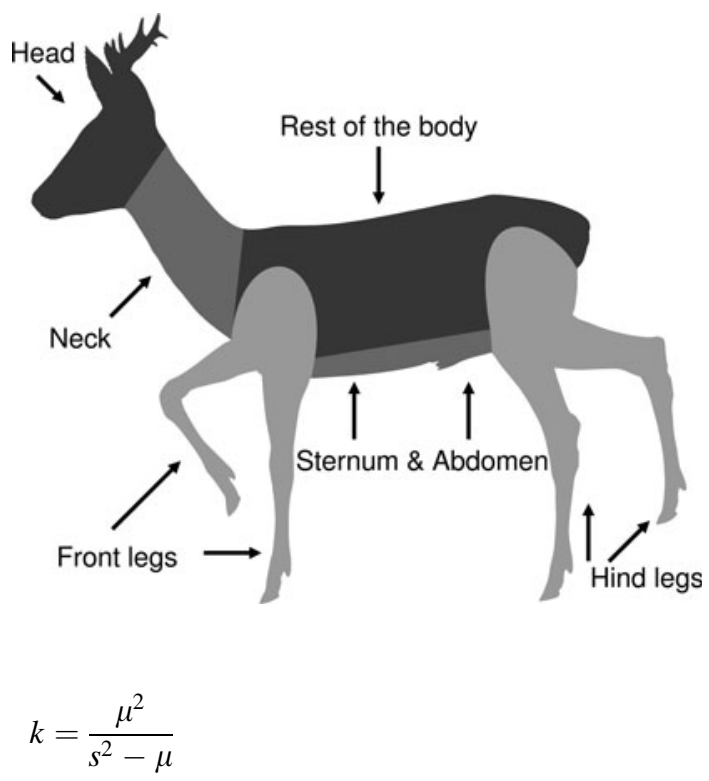

where $s^{2}$ is the variance of the sample. Small values $(k<1)$ indicate a high level of aggregation, while $k$ values $>5$ indicate randomness (Crawley 2005).

In order to provide equations which can be used to estimate tick burdens based on counts of selected body parts, we pooled all tick counts and calculated correlations (Kendall's $T$ ) between tick life stage abundance on one body part and life stage abundance on other body parts and the total number of this life stage on the entire roe deer carcass (Table 2). For each tick life stage, we selected the body part correlating most strongly with the total number of this life stage on the entire roe deer and fitted a linear regression model:

$$
y=a+b(x)
$$

where $y$ is the total number of the life stage on the entire roe deer, $a$ the intercept, $b$ the slope of the regression and $x$ the number of the tick life stage on the selected body part. We used SPSS 17.0 (SPSS Inc.) and R 2.51 (R Development Core Team) for analysing the data.

\section{Results}

In total, we sampled ticks from 91 roe deer. Eleven heads of roe deer had been removed by hunters prior to investigation, resulting in 80 complete tick-roe deer data sets. In sum we collected 5,159 ticks of which 862 were larvae, 1,912 were nymphs, 1,714 were females and 671 were males. The mean tick burden per roe deer was $64.49( \pm 10.62)$, and the tick burden was highly aggregated $(k=0.46)$.

On average, nymphs were the most numerous tick life stage on roe deer $(23.90 \pm 3.21)$, followed by females $(21.43 \pm 3.47)$, larvae $(10.78 \pm 4.18)$ and males $(8.39 \pm 1.52)$. The range of life stage specific tick burden per roe deer was wide: 0-255 larvae, 0-167 nymphs, $0-157$ females, $0-72$ males and 0-582 ticks combined. Levels of aggregation were highest in larvae $(k=0.08)$, followed by males $(k=0.40)$, females $(k=0.49)$ and nymphs $(k=0.71)$. 





Table 2 Correlations (Kendall's tau) between numbers of tick life stages/tick sex on one body part with tick numbers of the same life stage/sex on other body parts and on the entire roe deer body

\begin{tabular}{|c|c|c|c|c|c|c|c|}
\hline & & Head & Neck & $\begin{array}{l}\text { Rest of } \\
\text { the body }\end{array}$ & $\begin{array}{l}\text { Sternum \& } \\
\text { abdomen }\end{array}$ & $\begin{array}{l}\text { Front } \\
\text { legs }\end{array}$ & $\begin{array}{l}\text { Hind } \\
\text { legs }\end{array}$ \\
\hline Neck-Larvae & $\begin{array}{l}\text { Kendall's tau } \\
P \text {-value } \\
n\end{array}$ & $\begin{array}{l}0.558 \\
<0.001 \\
80\end{array}$ & & & & & \\
\hline $\begin{array}{l}\text { Rest of the } \\
\text { body-Larvae }\end{array}$ & $\begin{array}{l}\text { Kendall's tau } \\
P \text {-value } \\
n\end{array}$ & $\begin{array}{l}0.472 \\
<0.001 \\
80\end{array}$ & $\begin{array}{l}0.778 \\
<0.001 \\
91\end{array}$ & & & & \\
\hline $\begin{array}{l}\text { Sternum \& } \\
\text { abdomen-Larvae }\end{array}$ & $\begin{array}{l}\text { Kendall's tau } \\
P \text {-value } \\
n\end{array}$ & $\begin{array}{l}0.474 \\
<0.001 \\
80\end{array}$ & $\begin{array}{l}0.643 \\
<0.001 \\
91\end{array}$ & $\begin{array}{l}0.776 \\
<0.001 \\
91\end{array}$ & & & \\
\hline Front legs-Larvae & $\begin{array}{l}\text { Kendall's tau } \\
P \text {-value } \\
n\end{array}$ & $\begin{array}{l}0.445 \\
<0.001 \\
80\end{array}$ & $\begin{array}{l}0.585 \\
<0.001 \\
91\end{array}$ & $\begin{array}{l}0.581 \\
<0.001 \\
91\end{array}$ & $\begin{array}{l}0.491 \\
<0.001 \\
91\end{array}$ & & \\
\hline Hind legs-Larvae & $\begin{array}{l}\text { Kendall's tau } \\
P \text {-value } \\
n\end{array}$ & $\begin{array}{l}0.45 \\
<0.001 \\
80\end{array}$ & $\begin{array}{l}0.444 \\
<0.001 \\
91\end{array}$ & $\begin{array}{l}0.565 \\
<0.001 \\
91\end{array}$ & $\begin{array}{l}0.673 \\
<0.001 \\
91\end{array}$ & $\begin{array}{l}0.439 \\
<0.001 \\
91\end{array}$ & \\
\hline Entire body-Larvae & $\begin{array}{l}\text { Kendall's tau } \\
P \text {-value } \\
n\end{array}$ & $\begin{array}{l}0.69 \\
<0.001 \\
80\end{array}$ & $\begin{array}{l}0.628 \\
<0.001 \\
80\end{array}$ & $\begin{array}{l}0.598 \\
<0.001 \\
80\end{array}$ & $\begin{array}{l}0.58 \\
<0.001 \\
80\end{array}$ & $\begin{array}{l}0.817 \\
<0.001 \\
80\end{array}$ & $\begin{array}{l}0.553 \\
<0.001 \\
80\end{array}$ \\
\hline Neck-Nymphs & $\begin{array}{l}\text { Kendall's tau } \\
P \text {-value } \\
n\end{array}$ & $\begin{array}{l}0.494 \\
<0.001 \\
80\end{array}$ & & & & & \\
\hline $\begin{array}{l}\text { Rest of the } \\
\text { body-Nymphs }\end{array}$ & $\begin{array}{l}\text { Kendall's tau } \\
P \text {-value } \\
n\end{array}$ & $\begin{array}{l}0.23 \\
0.014 \\
80\end{array}$ & $\begin{array}{l}0.306 \\
0.002 \\
91\end{array}$ & & & & \\
\hline $\begin{array}{l}\text { Sternum \& } \\
\text { abdomen-Nymphs }\end{array}$ & $\begin{array}{l}\text { Kendall's tau } \\
P \text {-value } \\
n\end{array}$ & $\begin{array}{l}0.302 \\
0.001 \\
80\end{array}$ & $\begin{array}{l}0.318 \\
0.001 \\
91\end{array}$ & $\begin{array}{l}0.422 \\
<0.001 \\
91\end{array}$ & & & \\
\hline Front legs-Nymphs & $\begin{array}{l}\text { Kendall's tau } \\
P \text {-value } \\
n\end{array}$ & $\begin{array}{l}0.456 \\
<0.001 \\
80\end{array}$ & $\begin{array}{l}0.39 \\
<0.001 \\
91\end{array}$ & $\begin{array}{l}0.276 \\
0.003 \\
91\end{array}$ & $\begin{array}{l}0.347 \\
<0.001 \\
91\end{array}$ & & \\
\hline Hind legs-Nymphs & $\begin{array}{l}\text { Kendall's tau } \\
P \text {-value } \\
n\end{array}$ & $\begin{array}{l}0.408 \\
<0.001 \\
80\end{array}$ & $\begin{array}{l}0.441 \\
<0.001 \\
91\end{array}$ & $\begin{array}{l}0.272 \\
0.005 \\
91\end{array}$ & $\begin{array}{l}0.391 \\
<0.001 \\
91\end{array}$ & $\begin{array}{l}0.527 \\
<0.001 \\
91\end{array}$ & \\
\hline Entire body-Nymphs & $\begin{array}{l}\text { Kendall's tau } \\
P \text {-value } \\
n\end{array}$ & $\begin{array}{l}0.883 \\
<0.001 \\
80\end{array}$ & $\begin{array}{l}0.554 \\
<0.001 \\
80\end{array}$ & $\begin{array}{l}0.28 \\
0.003 \\
80\end{array}$ & $\begin{array}{l}0.385 \\
<0.001 \\
80\end{array}$ & $\begin{array}{l}0.584 \\
<0.001 \\
80\end{array}$ & $\begin{array}{l}0.5 \\
<0.001 \\
80\end{array}$ \\
\hline Neck-Females & $\begin{array}{l}\text { Kendall's tau } \\
P \text {-value } \\
n\end{array}$ & $\begin{array}{l}0.686 \\
<0.001 \\
80\end{array}$ & & & & & \\
\hline $\begin{array}{l}\text { Rest of the } \\
\text { body-Females }\end{array}$ & $\begin{array}{l}\text { Kendall's tau } \\
P \text {-value } \\
n\end{array}$ & $\begin{array}{l}0.494 \\
<0.001 \\
80\end{array}$ & $\begin{array}{l}0.571 \\
<0.001 \\
91\end{array}$ & & & & \\
\hline
\end{tabular}


Table 2 continued

\begin{tabular}{|c|c|c|c|c|c|c|c|}
\hline & & Head & Neck & $\begin{array}{l}\text { Rest of } \\
\text { the body }\end{array}$ & $\begin{array}{l}\text { Sternum \& } \\
\text { abdomen }\end{array}$ & $\begin{array}{l}\text { Front } \\
\text { legs }\end{array}$ & $\begin{array}{l}\text { Hind } \\
\text { legs }\end{array}$ \\
\hline $\begin{array}{l}\text { Sternum \& } \\
\text { abdomen-Females }\end{array}$ & $\begin{array}{l}\text { Kendall's tau } \\
P \text {-value } \\
n\end{array}$ & $\begin{array}{l}0.254 \\
0.007 \\
80\end{array}$ & $\begin{array}{l}0.359 \\
<0.001 \\
91\end{array}$ & $\begin{array}{l}0.337 \\
<0.001 \\
91\end{array}$ & & & \\
\hline Front legs-Females & $\begin{array}{l}\text { Kendall's tau } \\
P \text {-value } \\
n\end{array}$ & $\begin{array}{l}0.557 \\
<0.001 \\
80\end{array}$ & $\begin{array}{l}0.524 \\
<0.001 \\
91\end{array}$ & $\begin{array}{l}0.492 \\
<0.001 \\
91\end{array}$ & $\begin{array}{l}0.328 \\
<0.001 \\
91\end{array}$ & & \\
\hline Hind legs-Females & $\begin{array}{l}\text { Kendall's tau } \\
P \text {-value } \\
n\end{array}$ & $\begin{array}{l}0.474 \\
<0.001 \\
80\end{array}$ & $\begin{array}{l}0.5 \\
<0.001 \\
91\end{array}$ & $\begin{array}{l}0.372 \\
<0.001 \\
91\end{array}$ & $\begin{array}{l}0.334 \\
<0.001 \\
91\end{array}$ & $\begin{array}{l}0.505 \\
<0.001 \\
91\end{array}$ & \\
\hline Entire body-Females & $\begin{array}{l}\text { Kendall's tau } \\
P \text {-value } \\
n\end{array}$ & $\begin{array}{l}0.764 \\
<0.001 \\
80\end{array}$ & $\begin{array}{l}0.818 \\
<0.001 \\
80\end{array}$ & $\begin{array}{l}0.532 \\
<0.001 \\
80\end{array}$ & $\begin{array}{l}0.407 \\
<0.001 \\
80\end{array}$ & $\begin{array}{l}0.671 \\
<0.001 \\
80\end{array}$ & $\begin{array}{l}0.606 \\
<0.001 \\
80\end{array}$ \\
\hline Neck-Males & $\begin{array}{l}\text { Kendall's tau } \\
P \text {-value } \\
n\end{array}$ & $\begin{array}{l}0.663 \\
<0.001 \\
80\end{array}$ & & & & & \\
\hline Rest of the body-Males & $\begin{array}{l}\text { Kendall's tau } \\
P \text {-value } \\
n\end{array}$ & $\begin{array}{l}0.552 \\
<0.001 \\
80\end{array}$ & $\begin{array}{l}0.559 \\
<0.001 \\
91\end{array}$ & & & & \\
\hline $\begin{array}{l}\text { Sternum \& } \\
\text { abdomen-Males }\end{array}$ & $\begin{array}{l}\text { Kendall's tau } \\
P \text {-value } \\
n\end{array}$ & $\begin{array}{l}0.415 \\
<0.001 \\
80\end{array}$ & $\begin{array}{l}0.452 \\
<0.001 \\
91\end{array}$ & $\begin{array}{l}0.503 \\
<0.001 \\
91\end{array}$ & & & \\
\hline Front legs-Males & $\begin{array}{l}\text { Kendall's tau } \\
P \text {-value } \\
n\end{array}$ & $\begin{array}{l}0.452 \\
<0.001 \\
80\end{array}$ & $\begin{array}{l}0.579 \\
<0.001 \\
91\end{array}$ & $\begin{array}{l}0.499 \\
<0.001 \\
91\end{array}$ & $\begin{array}{l}0.419 \\
<0.001 \\
91\end{array}$ & & \\
\hline Hind legs-Males & $\begin{array}{l}\text { Kendall's tau } \\
P \text {-value } \\
n\end{array}$ & $\begin{array}{l}0.416 \\
<0.001 \\
80\end{array}$ & $\begin{array}{l}0.505 \\
<0.001 \\
91\end{array}$ & $\begin{array}{l}0.478 \\
<0.001 \\
91\end{array}$ & $\begin{array}{l}0.381 \\
<0.001 \\
91\end{array}$ & $\begin{array}{l}0.436 \\
<0.001 \\
91\end{array}$ & \\
\hline Entire body-Males & $\begin{array}{l}\text { Kendall's tau } \\
P \text {-value } \\
n\end{array}$ & $\begin{array}{l}0.749 \\
<0.001 \\
80\end{array}$ & $\begin{array}{l}0.851 \\
<0.001 \\
80\end{array}$ & $\begin{array}{l}0.577 \\
<0.001 \\
80\end{array}$ & $\begin{array}{l}0.553 \\
<0.001 \\
79\end{array}$ & $\begin{array}{l}0.587 \\
<0.001 \\
80\end{array}$ & $\begin{array}{l}0.559 \\
<0.001 \\
80\end{array}$ \\
\hline Neck-Ticks & $\begin{array}{l}\text { Kendall's tau } \\
P \text {-value } \\
n\end{array}$ & $\begin{array}{l}0.673 \\
<0.001 \\
80\end{array}$ & & & & & \\
\hline Rest of the body-Ticks & $\begin{array}{l}\text { Kendall's tau } \\
P \text {-value } \\
n\end{array}$ & $\begin{array}{l}0.52 \\
<0.001 \\
80\end{array}$ & $\begin{array}{l}0.61 \\
<0.001 \\
91\end{array}$ & & & & \\
\hline $\begin{array}{l}\text { Sternum \& } \\
\text { abdomen-Ticks }\end{array}$ & $\begin{array}{l}\text { Kendall's tau } \\
P \text {-value } \\
n\end{array}$ & $\begin{array}{l}0.539 \\
<0.001 \\
80\end{array}$ & $\begin{array}{l}0.544 \\
<0.001 \\
91\end{array}$ & $\begin{array}{l}0.52 \\
<0.001 \\
91\end{array}$ & & & \\
\hline Front legs-Ticks & $\begin{array}{l}\text { Kendall's tau } \\
P \text {-value } \\
n\end{array}$ & $\begin{array}{l}0.6 \\
<0.001 \\
80\end{array}$ & $\begin{array}{l}0.596 \\
<0.001 \\
91\end{array}$ & $\begin{array}{l}0.575 \\
<0.001 \\
91\end{array}$ & $\begin{array}{l}0.579 \\
<0.001 \\
91\end{array}$ & & \\
\hline
\end{tabular}


Table 2 continued

\begin{tabular}{llllllll}
\hline & & Head & Neck & $\begin{array}{l}\text { Rest of } \\
\text { the body }\end{array}$ & $\begin{array}{l}\text { Sternum \& } \\
\text { abdomen }\end{array}$ & $\begin{array}{l}\text { Front } \\
\text { legs }\end{array}$ & $\begin{array}{l}\text { Hind } \\
\text { legs }\end{array}$ \\
\hline Hind legs-Ticks & Kendall's tau & 0.593 & 0.64 & 0.495 & 0.571 & 0.615 \\
& $P$-value & $<0.001$ & $<0.001$ & $<0.001$ & $<0.001$ & $<0.001$ \\
& $n$ & 80 & 91 & 91 & 91 & 91 & 0.699 \\
Entire body-Ticks & Kendall's tau & $\mathbf{0 . 8 4 9}$ & 0.772 & 0.593 & 0.616 & 0.704 & $<0.001$ \\
& $P$-value & $\mathbf{< . 0 0 1}$ & $<0.001$ & $<0.001$ & $<0.001$ & $<0.001$ & 80 \\
\hline
\end{tabular}

The strongest correlations between tick life stages on one body part and entire life stage burden are highlighted in bold

\section{Abundance estimation}

Life stage specific tick numbers on one body part were significantly correlated with life stage specific tick numbers on all other body parts and with the entire life stage burden (Table 2).

For Ixodes larvae, the counts on the front legs correlated most strongly with the entire larvae burden (Table 2). Fitting a linear regression to these data (Fig. 2a) resulted in a significant predictive model $(F=419, \mathrm{DF}=1,78, P \ll 0.001)$ which explains a considerable amount of the observed variance (adjusted $R^{2}=0.841$ ). Figures in brackets indicate the standard error of each regression coefficient.

Larvae on entire roe deer $=3.38( \pm 1.71)+1.41( \pm 0.07) \times$ larvae on front legs

For Ixodes nymphs, the tick count on the head was chosen as predictor for the entire nymph burden (Table 2). The fitted linear relationship for these data (Fig. 2b) was highly significant $(F=270.7, \mathrm{DF}=1,78, P \ll 0.001)$ and explained ca. $77 \%$ of the variance (adjusted $R^{2}=0.773$ ).

Nymphs on entire roe deer $=2.27( \pm 2.02)+1.28( \pm 0.08) \times$ nymphs on head

For the adult ticks, the tick counts on the neck were selected to predict the total female and male tick abundance (Table 2). For female ticks (Fig. 2c), a linear model $(F=752.8$, $\mathrm{DF}=1,78, P \ll 0.001)$ explained ca. $90 \%$ of the variance (adjusted $R^{2}=0.905$ ):

Females on entire roe deer $=5.87( \pm 1.21)+1.61( \pm 0.06) \times$ females on neck

For male ticks (Fig. 2d), the corresponding model $(F=827.3, \mathrm{DF}=1,78, P \ll 0.001)$ explained ca. $91 \%$ of the variance (adjusted $R^{2}=0.913$ ):

Males on entire roe deer $=1.86( \pm 0.50)+1.57( \pm 0.05) \times$ males on neck

For all ticks combined, tick counts on the head appeared to be the best predictor for total tick burden (Table 2). This relationship (Fig. 3) was also described with a linear model $(F=149.3, \mathrm{DF}=1,78, P \ll 0.001)$ and explained ca. $65 \%$ of the variance (adjusted $\left.R^{2}=0.653\right)$ :

Ticks on entire roe deer $=-3.06( \pm 8.35)+2.66( \pm 0.22) \times$ Ticks on head 

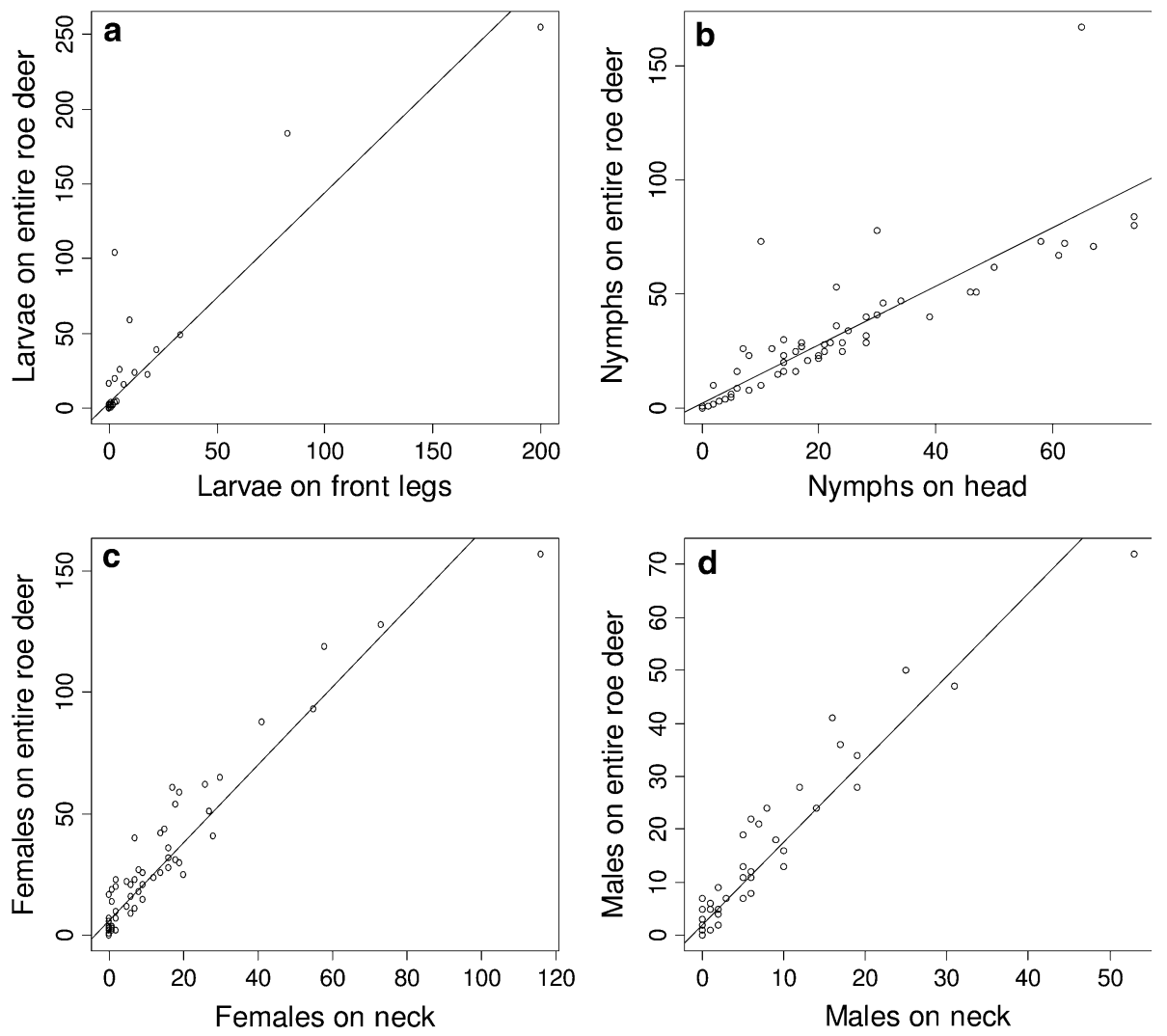

Fig. 2 Linear regression plots showing the relationship between number of larvae (a), nymphs (b), females (c) and males (d) on one body part and predicted number of each tick life stage on the entire roe deer body

\section{Discussion}

Based on entire body counts of 80 hunter-killed roe deer we present life stage specific tick burdens of roe deer and linear models which can be used to extrapolate tick burdens on roe deer based on tick counts on selected body parts.

Although the tick examination was carried out with extraordinary diligence, we cannot exclude that some (i.e. larval) ticks were missed (MacIvor et al. 1987). It is however unlikely that ticks detached prior to the investigation; detached ticks were never observed in trays underneath the carcasses. A few ticks, especially in the abdomen region may have been missed because parts of the abdomen hide had been removed by the hunter during the disembowelling of the carcass. Thus, reported tick numbers should be regarded as minimum numbers.

It is difficult to compare Ixodes tick burdens of roe deer with those of other host species such as sheep (Ogden et al. 1998), due to the considerable effect of season on tick parasitism (Randolph 2004). Nevertheless, tick numbers on roe deer in the summer months can be characterised as very high (up to 582 ticks/individual). Over the year, roe deer are parasitized by all four Ixodes life stages/sexes, whereas adult ticks combined (females 33\% 


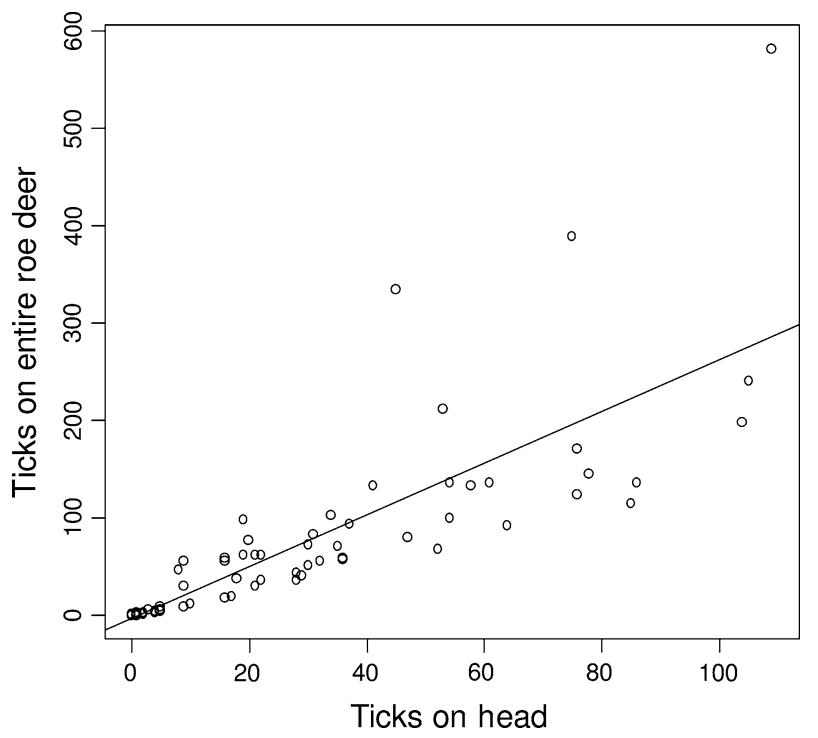

Fig. 3 Linear regression plot showing the relationship between the number of ticks (all life stages combined) attached on the head and predicted number of ticks on the entire roe deer body

of all ticks + males $13 \%$ of all ticks) make up $\sim 46 \%$ of the total tick burden. Nymphs are very abundant on roe deer as well, whereas larvae appear to be extremely aggregated on few individual deer $(k=0.08)$. This extreme level of aggregation is probably a consequence of the strong seasonality in larvae activity (Randolph et al. 1999) and the spatial aggregation of questing larvae ticks in the vegetation.

Estimating life stage abundance based on restricted counts

For assessing abundance of nymphs and adult Ixodes ticks, it is sufficient to sample the head and the neck of roe deer. For best approximating larvae burden, additional tick counts on the front legs are required. However, larvae counts on the head offer the second best equation for extrapolating larvae burden $(F=72.3$, DF $=1,78, P \ll 0.001$, adjusted $\left.R^{2}=0.474\right)$ :

Larvae on entire roe deer $=2.53( \pm 3.18)+5.74( \pm 0.67) \times$ larvae on head

It is thus reasonable to restrict tick counts to the head and the neck in order to estimate life stage specific tick burdens on roe deer.

Whenever possible, tick life stage/sex specific counts and models should be applied for estimating total tick burdens of roe deer. The model based on the combined tick count (Fig. 3) shows a rather large variance and the model's intercept is associated with a large margin of error, thus questioning the reliability of this model.

The presented tick life stage or sex specific models show good fits and explain a large amount of the observed variance in tick parasitism and thus offer a robust basis for rapid tick abundance assessment. 
Acknowledgments Representative for all hunters and forest rangers involved we would like to thank J. Berger, D. Birke, E. Kreysern, W. Mänz, M. Scholz, and R. Zietlow for making the roe deer available for this study. We sincerely thank K. Hammer, H. Lippe, A. and M. Lödige, M. Scholz and several other students for their help during the field work. We thank B. Wilson for linguistic improvements of the manuscript. This study was funded by a research grant from the Federal Ministry of Education and Research (BMBF grant 1363120: Emerging arthropod-borne-viral infections in Germany: Pathogenesis, diagnostics and surveillance).

Open Access This article is distributed under the terms of the Creative Commons Attribution Noncommercial License which permits any noncommercial use, distribution, and reproduction in any medium, provided the original author(s) and source are credited.

\section{References}

Barnard DR, Morrison RD (1985) Density estimators for populations of the lone star tick, Amblyoma americanum (Acari: Ixodidae), on pastured beef cattle. J Med Entomol 22:244-249

Barnard DR, Morrsion RD, Ervin T (1989) Sites of attachment and density assessment in Amblyoma americanum (Acari: Ixodidae) on nursing beef calves. Exp Appl Acarol 6:245-252

Bloemer SR, Zimmermann RH, Fairbanks K (1988) Abundance, attachment sites, and density estimators of lone star ticks (Acari: Ixodidae) infesting white tailed deer. J Med Entomol 25:295-300

Borchers DL, Buckland ST, Zucchini W (2002) Estimating animal abundance: closed populations. Springer, London

Bruno P, Bruno G, Peréz-Eid C (2000) Detection of spirochaetes of Borrelia burgdorferi complexe in the skin of cervids by PCR and culture. Eur J Epidemiol 16:869-873

Carpi G, Cagnacci F, Neteler M et al (2008) Tick infestation on roe deer in relation to geographic and remotely sensed climatic variables in a tick-borne encephalitis endemic area. Epidemiol Infect 136:1416-1424

Crawley MJ (2005) Statistics: an introduction using R. Wiley, The Atrium, Southern Gate, Chichester, West Sussex

Fish D, Childs JE (2009) Community-based prevention of Lyme disease and other tick-borne diseases through topical application of acaricide to white-tailed deer: background and rationale. Vector-Borne Zoonotic Dis 9:357-364

Fourie LJ, Kok DJ (1995) A comparison of Ixodes rubicundus infestations on Friesian and Bonsmara cattle in South Africa. Exp Appl Acarol 19:529-531

Fourie LJ, van Zyl JM (1991) Interspecific variations in attachment sites and density assessment in female Ixodes rubicundus (Acari: Ixodidae) on domestic and natural hosts. Exp Appl Acarol 13:1-10

Fourie LJ, Horak IG, van Zyl JM (1991) Sites of attachment and intraspecific infestation densities of the brown paralysis tick Rhipicephalus punctatus on Angora goats. Exp Appl Acarol 12:243-249

Hartemink NA, Randolph SE, Davis SA, Heesterbeek JAP (2008) The basic reproduction number for complex disease systems: defining $R_{0}$ for tick borne infections. Am Nat 171:743-754

Jaenson TG, Tälleklint L (1992) Incompetence of roe deer as reservoirs of the Lyme borreliosis spirochete. J Med Entomol 29:813-817

Jongejan F, Uilenberg G (2004) The global importance of ticks. Parasitology 129:S3-S14

Kimura K, Isogai E, Isogai $\mathrm{H}$ et al (1995) Detection of Lyme disease spirochetes in the skin of naturally infected wild sika deer (Cervus nippon yesoensis). Appl Environ Microbiol 61:1641-1642

L'Hostis M, Diarra O, Seegers H (1994) Sites of attachment and density assessment of female Ixodes ricinus (Acari: Ixodidae) on dairy cows. Exp Appl Acarol 18:681-689

MacIvor KM, Horak IG, Holton KC et al (1987) A comparison of live and destructive sampling methods of determining the size of parasitic tick populations. Exp Appl Acarol 3:131-143

Mathee S, Meltzer DGA, Horak IG (1997) Sites of attachment and density assessment of ixodid ticks (Acari: Ixodidae) on impala (Aepyceros melampus). Exp Appl Acarol 21:179-192

Matuschka FR, Heiler M, Eiffert H et al (1993) Diversionary role of hoofed game in the transmission of Lyme disease spirochetes. Amer J Trop Med Hyg 48:693-699

Ogden NH, Nuttal PA, Randolph SE (1997) Natural Lyme disease cycles maintained via sheep by cofeeding ticks. Parasitology 115:591-599

Ogden NH, Hailes RS, Nuttall PA (1998) Interstadial variation in the attachment sites of Ixodes ricinus ticks on sheep. Exp Appl Acarol 22:227-232 
Petritian AM, von Lüpke B, Petritan IC (2007) Effects of shade on growth and mortality of maple (Acer pseudoplatanus), ash (Fraxinus excelsior) and beech (Fagus sylvatica) saplings. Forestry 80:397-412

Pound JM, Miller JA, George JE et al (2009) The United States department of agriculture's northeast areawide tick control project: summary and conclusions. Vector-Borne Zoonotic Dis 9:439-448

Rand PW, Lacombe EH, Holman MS et al (2000) Attempt to control ticks (Acari: Ixodidae) on deer on an isolated island using ivermectin-treated corn. J Med Entomol 37:126-133

Randolph SE (2004) Tick ecology: processes and patterns behind the epidemiological risk posed by ixodid ticks as vectors. Parasitology 129:S37-S65

Randolph SE, Gern L, Nuttall PA (1996) Co-feeding ticks: epidemiological significance for tick-borne pathogen transmission. Parastitology Today 12:472-479

Randolph SE, Miklisová D, Lysy J et al (1999) Incidence from coincidence: patterns of tick infestations on rodents facilitate transmission of tick-borne encephalitis virus. Parasitology 118:177-186

Schmid KA, Ostfeld RS (2001) Biodiversity and the dilution effect in disease ecology. Ecology 82:609-619

Schmidtmann ET, Caroll JF, Watson DW (1998) Attachment site patterns of adult blacklegged ticks (Acari: Ixodidae) on white-tailed deer and horses. J Med Entomol 35:59-63

Shaw DJ, Grenfell BT, Dobson AP (1998) Patterns of macroparasite aggregation in wildlife host populations. Parasitology 117:597-610

Sutherland WJ (ed) (1996) Ecological census techniques: a handbook. Cambridge University Press, Cambridge 